\title{
Ocular lesions in HTLV-1 infected patients from Salvador, State of Bahia: the city with the highest prevalence of this infection in Brazil
}

\author{
Lesões oculares em pacientes infectados pelo HTLV-1 em Salvador, Estado da \\ Bahia: a cidade com maior prevalência desta infecção no Brasil
}

\author{
Regina Helena Rathsam-Pinheiro, ${ }^{1,2}$, Ney Boa-Sorte², Cristina Castro-Lima-Vargens ${ }^{1}$, \\ Carlos Aldir Pinheiro ${ }^{1,2}$, Humberto Castro-Lima ${ }^{1,2, \dagger}$ and Bernardo Galvão-Castro ${ }^{2,3}$
}

\begin{abstract}
In order to determine the prevalence of ocular lesions in HTLV-1 infected patients in Salvador Bahia, a transversal study was conducted on 140 HTLV-1 infected patients (90 asymptomatic and 50 tropical spastic paraparesis/HTLV-1-associated myelopathy) between June 2004 and November 2005 . The ophthalmological examination included visual acuity measurement, ocular motility, biomicroscopy of the anterior and posterior chambers, intraocular pressure and evaluation of lachrymal secretion. Observation verified 4 (2.8\%) out of 140 patients with uveitis (two patients had intermediate uveitis and two had pan-uveitis) and 39 (36.4\%) out of 107 patients with keratoconjunctivitis sicca. The prevalence of Keratoconjunctivitis sicca was significantly higher among the TSP/HAM patients (OR age adjusted=3.64; 95\%CI 1.59-8.32). Uveitis and corneal opacities were also important findings, indicating the strong need for periodic ophthalmological follow-up in all HTLV-1 subjects.
\end{abstract}

Key-words: HTLV-1. Ocular lesions. Uveitis. Keratoconjunctivitis sicca. Corneal opacities.

\section{RESUMO}

Com o objetivo de determinar a prevalência de lesões oculares, em portadores de HTLV-1 em Salvador, Bahia, foi realizado um estudo transversal em 140 pacientes (90 assintomático e 50 com paraparesia espática tropical/mielopatia associada ao vírus linfotrópico de células T humanas) entre junho de 2004 e novembro de 2005. 0 exame oftalmológico incluiu medida da acuidade visual, exame da motilidade ocular, biomicroscopia anterior e posterior, pressão intraocular e avaliação do filme lacrimal. Observamos $4.0(2.8 \%)$ pacientes com uveites (dois com uveíte intermediária e dois com panuveíte) e 39 (36,4\%) pacientes com ceratoconjuntivite seca. A prevalência de Ceratoconjuntivite seca foi significantemente mais elevada entre os pacientes com TSP/HAM (RC ajustada para idade = 3,64; IC 95\% 1,59-8,32). As uveítes e opacidades corneanas foram também, patologias importantes, indicando a necessidade de acompanhamento oftalmológico periódico nos portadores de HTLV-1.

Palavras-chaves: HTLV-1. Lesões oculares. Uveítes. Ceratoconjuntivite seca. Opacidades corneanas.

Human T cell lymphotropic virus type 1 (HTLV-1) was identified in $1980^{31}$. Transmission occurs through sexual contact, blood transfusion and sharing of injection equipment, as well as vertically from mother to child, mainly through breast-feeding ${ }^{1632}$. HTLV-1 infection is prevalent in Japan, Melanesia, the Caribbean Islands, Central and South America, as well in some regions of Africa, and it is estimated that 20 million people carry the virus worldwide ${ }^{54}$. This virus is etiologically linked with adult $\mathrm{T}$ cell

1. Instituto Brasileiro de Oftalmologia e Prevenção da Cegueira (IBOPC), Salvador-BA. 2. Escola Bahiana de Medicina e Saúde Pública (EBMSP), Salvador, BA. 3. Laboratório Avançado de Saúde Publica, Centro de Pesquisas Gonçalo Moniz, Fundação Oswaldo Cruz (LASP/CPqGM/0FIOCRUZ), Salvador-BA. †Deceased.

Suporte financeiro parcial: CNPq.

Address to: Dr. Bernardo Galvão-Castro. Centro Integrativo e Multidisciplinar de HTLV e Hepatites Virais/Escola Bahiana de Medicina e Saúde Pública. Av. Dom João VI 274, Brotas, 40290-000 Salvador, BA.

Tel: 5571 3276-8281; Fax: 5571 3276-8290

e-mail: bgalvao@bahiana.edu.br

Recebido em 30/10/2008

Aceito em 14/10/2009 leukemia (ATL), tropical spastic paraparesis/HTLV-1-associated myelopathy (TSP/HAM), infective dermatitis and uveitis (HTLV-1associated uveitis [HAU]) $)^{10} 1521232936$. Many other diseases have been associated with HTLV-1, such as polymyositis, sinusitis, thyroiditis, bronchial alveolar pneumonia, Sjörgren's Syndrome, indicating a multisystemic involvement in this infection ${ }^{6} 32$. Moreover, other ocular lesions can also be associated with HTLV-1, such as keratoconjunctivitis sicca (KCS), corneal lesions and retinal vasculitis ${ }^{3817192030}$. Controversial results exist concerning the prevalence of HAU in different parts of the world. For instance, in Japan a 35.4\% of HAU prevalence was observed, while in Martinique, the prevalence was $14.5 \%^{12}{ }^{18}$. In Brazil, the prevalence rate $(1.9 \%$ to $2.8 \%)$ of HAU is lower than that reported in $\operatorname{Japan}^{30} 35$.

Salvador, the capital of the State of Bahia located in the Northeast of Brazil, has the highest prevalence of HTLV-1 in the country9. The prevalence of HTLV-1 was $1.7 \%$ in a population based study and it was estimated that 40,000 people could be 
infected by HTLV-1 in the city ${ }^{4}$. HTLV-1 associated pathologies, such as TSP/HAM ATL and infective dermatitis, have been widely identified in patients from Salvador ${ }^{11}{ }^{11}$. However, there have been no studies concerning ocular lesions associated with HTLV-1 infection in this city. Therefore, it is of paramount importance to determine the prevalence of ocular diseases in order to estimate the magnitude of this health problem in Salvador.

\section{MATERIAL AND METHODS}

Study design and population. An out-patient crosssectional study was conducted between June 2004 and November 2005 at the Integrative and Multidisciplinary Center for HTLV and Viral Hepatitis (Centro Integrativo e Multidisciplinar de HTLV e Hepatites Virais), Bahia School of Medicine and Public Health (Escola Babiana de Medicina e Saúde Pública, ECMSP), Salvador, Bahia, Brazil, where an interdisciplinary project including medical care, laboratory diagnosis, psychological assistance and physiotherapy is being conducted. At the time of the realization of this project 385, HTLV-1 infected patients were well characterized regarding their sociodemographic profile, laboratory diagnosis and clinical status. Most of them were women from low social classes and $110(30.2 \%)$ had TSP/HAM ${ }^{26}$. All the patients were invited to participate and 140 of them accepted and were enrolled in the study. All the volunteers provided written informed consent before entering the research protocol. The Ethics Committee of EBMSP approved this study.

Laboratory, clinical and ophthalmologic diagnosis. HTLV-1 infection was assessed according to the algorithm recommended by the Brazilian Ministry of Health ${ }^{33}$. Briefly, plasma samples repeatedly positive in duplicate by ELISA (HTLV-1/HTLV2 Ab-Capture ELISA Test System, Ortho. Clinical Diagnostic Inc. Raritan, New Jersey, USA) were confirmed and discriminated between HTLV-1 and HTLV-2 using Western Blot (HTLV Blot 2.4; Genelabs, Singapore). Polymerase Chain Reaction (PCR) analysis was performed in samples with undetermined results according to the technique described elsewhere ${ }^{13}$. The diagnosis of HAM/TSP was determined according to the WHO guidelines ${ }^{28}$

A full ophthalmologic examination was performed, including visual acuity measurement by Snellen eye chart, with optical correction, optical motility, applanation tonometry, biomicroscopy of the anterior and posterior chambers, binocular indirect ophthalmoscopy with or without depression, in both eyes and intraocular pressure. Evaluation of tear secretion was performed by BUT (break-up time), Rose Bengal and Schirmer I Tests. The Rose Bengal test was performed with $0.1 \%$ solution Rose Bengal staining and was considered pathological when the total score was higher than three points (Van-Bijsterveld score) ${ }^{14}$. Scores of $\leq 10$ seconds for break-up time and $\leq 5 \mathrm{~mm}$ for Schirmer I test were defined as abnormal. Diagnosis of KCS was based upon the presence of symptoms and at least two out of three positive test ${ }^{214}$.

Diagnosis of uveitis was defined by the presence of inflammatory cells in any segment of the uveal tract, active or episodes in the past $^{27}$. The anatomic classification determined by the International Uveitis Study Group, which classifies uveitis in anterior, intermediate, posterior and panuveitic was used $^{14}$. Each uveitis patient underwent serological evaluation for toxoplasmosis, syphilis, cytomegalovirus and HIV. These patients were also examined for signs of sarcoidosis, Behçet's disease and tuberculosis by clinical and X-ray evaluation for differential diagnosis. To confirm conjunctiva, corneal and lens alterations, anterior biomicroscopy was performed, while fundus manifestations were analyzed using posterior biomicroscopy and retinal evaluations.

Statistical analysis. The results were expressed as proportions for categorical variables and means \pm standard deviation (SD) for continuous variables. The statistical tests included the Student $t$ test for independent variables and Pearson chi square or the Fisher Exact test, for comparison of the ocular lesions and sociodemographic data between TSP/HAM patients and asymptomatic HTLV-1 carriers. Symptoms analysis was performed taking into account the patient's median age to verify age effects. Logistic regression was used to adjust the effect of age and gender on the relationship between CCS (dependent variable) and the presence of TSP/HAM (principal independent variable). Differences of $\mathrm{p}<0.05$ were considered statistically significant. All the data were stored and analyzed with Epi Info for Windows ${ }^{\circledR}$, version 3.2.2.

\section{RESULTS}

After informed consent, 140 HTLV-1 positive individuals were enrolled in this study. According to the WHO guidelines ${ }^{28}$ $50(35.7 \%)$ out 140 had been diagnosed with TSP/HAM and $90(64.3 \%)$ were asymptomatic. The sociodemographic and clinical data are shown in Table 1. Most patients described themselves as mulatto (52.2\%) or black (31.9\%). The majority (64.2\%) had not finished primary school and only 35.8\% had finished middle school. Regarding their origin and marital status, $85.7 \%$ of the patients were from Salvador and $40.3 \%$ were single and 38.8 married. Most of the patients were women (65\%), aged from 6 to 81 years-old, with a mean of $47.5( \pm 14.9)$ years-old. All of them were submitted to a completed ophthalmologic examination. Concerning the main ocular complaint, 70 (50\%) patients reported visual blurring, 52 (37.7\%) felt pain/burning, 33 (23.6\%) itching, 27 (19.3\%) tear flow, 18 (12.9\%) foreign body sensation, 9 (6.4\%) flying flies and 22 (15.7\%) had no ocular complaints. The main ocular complaints were analyzed in both groups of patients stratified by median age ( 47 years-old). Only the sensation of a foreign body was twice as frequent in patients who were over 47 years of age $(17.4 \%$ versus $8.5 \%$; $=0.11)$. Table 2 shows all ocular lesions in HTLV-1 patients. Other adnexal findings included hyperemia, pterygium, pinguecula and conjunctival nevus in $39(27.9 \%)$ patients. Corneal lesions were present in $17.1 \%$ of patients with 17 (12.1\%) presenting corneal opacities.

Four $(2.8 \%)$ individuals had anterior chamber alterations, such as fibrin, shallow anterior chamber and iridium pigments, $6(4.3 \%)$ had mild lens opacification, 7 (5\%) had pseudophakia, $1(0.7 \%)$ with iris atrophy, $2(1.4 \%)$ with corectopia, and $1(0.7 \%)$ with peripheral iridotomy. 
TABLE 1

Sociodemographic and clinical features of the $140 \mathrm{HTLV}-1$ infected patients recruited for the study, Salvador, Bahia, 2005-2006.

\begin{tabular}{|c|c|c|}
\hline Variables & Number & Percentage \\
\hline Age* (years) & $47.5 \pm 14.9$ & 6.81 \\
\hline \multicolumn{3}{|l|}{ Clinical Status } \\
\hline asymptomatic & 90 & 64.3 \\
\hline TSP/HAM & 50 & 35.7 \\
\hline \multicolumn{3}{|c|}{ Skin color (self-identified) } \\
\hline white & 22 & 15.7 \\
\hline mulatto & 72 & 51.4 \\
\hline black & 44 & 31.4 \\
\hline not informed & 02 & 1.5 \\
\hline \multicolumn{3}{|l|}{ Education } \\
\hline$\leq 8$ years & 88 & 62.9 \\
\hline$>8$ years & 49 & 35.0 \\
\hline not informed & 03 & 2.1 \\
\hline \multicolumn{3}{|l|}{ Marital status } \\
\hline single & 54 & 38.6 \\
\hline married & 52 & 37.1 \\
\hline divorced & 12 & 8.6 \\
\hline widow & 16 & 11.4 \\
\hline not informed & 06 & 4.3 \\
\hline \multicolumn{3}{|l|}{ Place of birth } \\
\hline \multicolumn{3}{|l|}{ Bahia State } \\
\hline Salvador City & 129 & 85.7 \\
\hline Other cities & 19 & 13.6 \\
\hline Other State & 01 & 0.7 \\
\hline \multicolumn{3}{|l|}{ Sex } \\
\hline male & 49 & 35 \\
\hline female & 91 & 65 \\
\hline
\end{tabular}

TSP/HAM: tropical spastic paraparesis/HTLV-1-associated myelopathy. * expressed by mean \pm standard deviation (minimum - maximum).

\section{TABLE 2}

Distribution of the ocular lesions of 140 patients examined between June 2004 and November 2005 in the HTLV-1 Center

\begin{tabular}{lrr}
\hline Ocular lesions & Number & Percentage \\
\hline Anterior segment & 39 & \\
conjunctiva & 24 & 17.1 \\
cornea & 5 & 3.6 \\
anterior chamber & 13 & 9.3 \\
lens & & \\
Posterior segment & 12 & 8.6 \\
retina & 4 & 2.8 \\
$\quad$ vitreous & & \\
Diagnosis & 39 & 36.4 \\
keratoconjuntivitis sicca & 4 & 2.86 \\
uveitis & 22 & 15.7 \\
$\quad$ corneal opacities & & \\
\hline
\end{tabular}

Concerning the posterior chamber, the following were verified: $1(0.7 \%)$ vitreous cell from a probable sequel of intermediate uveitis, $1(0.7 \%)$ vitreous organization from a probable sequel of panuveitis and 2 (1.4\%) posterior vitreous detachment (PVD). Retinal pathologies were seen in $10(7.1 \%)$ patients, $2(1.4 \%)$ sequelae from chorioretinitis, 2 exudates in patients with diabetic retinopathy and 10 (7.1\%) with druses, macular edema, macular pigments and scarce retinal epithelium.

Uveitis was diagnosed in 4 (2.8\%) patients, including two with intermediate uveitis and two with panuveitis. No significant differences were determined between the TSP/HAM and asymptomatic groups (Table 3 ).

Complete tear film evaluation was performed in 107 subjects leading to $39(36.4 \%)$ diagnoses of keratoconjunctivitis sicca (KCS). KCS was more frequent among TSP/HAM patients than in non-TSP/HAM patients $(\mathrm{OR}=3.88 ; 95 \% \mathrm{CI} 1.68-8.97)$. This association remained significant even after adjustment for age and sex $(\mathrm{OR}=3.35 ; 95 \% \mathrm{CI} 1.42-7.91)$.

TABLE 3

Comparison of demographic characteristics and ocular lesions among patients with and without TSP/HAM.

\begin{tabular}{lccc}
\hline & With TSP/HAM & Without TSP/HAM & p value \\
Characteristics & $\mathrm{n}=50$ & $\mathrm{n}=90$ & \\
\hline Female & $29 / 50(58.0 \%)$ & $62 / 90(68.9 \%)$ & 0.196 \\
Median age & $49.9 \pm 10.3$ & $46.2 \pm 16.8$ & 0.106 \\
Uveitis & $1 / 50(2.0 \%)$ & $3 / 90(3.3 \%)$ & $1.00^{*}$ \\
KCS $^{* * *}$ & $22 / 39(56.4 \%)$ & $17 / 68(25,0 \%)$ & 0.001 \\
\hline
\end{tabular}

*Fisher Exact Test, ***out of 140 patients, 107 were examined for Keratoconjuntivitis sicca, TSP/HAM: tropical spastic paraparesis/HTLV-1-associated myelopathy.

\section{DISCUSSION}

In this study, a full ophthalmologic examination was performed on the 140 patients, which verified that $2.8 \%$ were suffering from uveitis, 36.4\% from KCS and numerous ophthalmologic complaints were reported, confirming previous data ${ }^{1830}$. Analysis the sociodemographic characteristics of these HTLV-1 patients revealed that the great majority had incomplete primary education, were female and were over 40 years-old. This reflects the profile of the population of the HTLV-1 center and the main characteristics of the infection in Salvador, as described previously ${ }^{426}$.

Concerning the ophthalmologic complaints, the most frequent were: visual blurring (50\%), pain/burning (37.1\%) and itching (23.6\%). Foreign body sensation was twice as frequent in patients over 47 years-old ( $17.4 \%$ versus $8.5 \%$; $=0.114)$. These results are similar to those obtained in previous Brazilian studies and in other geographic regions, such as Martinique and Japan ${ }^{18} 1930$. Unfortunately, the lesions in these studies were not quantified and therefore no comparisons can be made.

Regarding uveitis ( 2 intermediate and 2 panuveitis), the $2.8 \%$ prevalence observed is very similar to that found in other regions of Brazil, but much lower than in Japan ${ }^{123035}$. Additionally, no difference in frequency was observed between patients with and without TSP/HAM, corroborating previous results. Indeed, prevalences of $1.93 \%$ and $1.82 \%$ in asymptomatic and HAM/TSP individuals, respectively, were observed in the City of Belo Horizonte, State of Minas Gerais, in the Southeast region of the country ${ }^{30}$. Only one study reported a prevalence of $11.8 \%$ of 
uveitis in TSP/HAM patients from Rio de Janeiro, also located in the same geographic region ${ }^{34}$. However, in this article, only the anterior uveitis was reported, in disagreement with most studies in Brazil and other countries where intermediate uveitis predominates ${ }^{20} 3035$. In contrast to the prevalence estimates obtained here, Merle et al ${ }^{18}$ and Mochizuki et al ${ }^{23}$ reported higher prevalence of uveitis in Martinique and Japan, respectively. This conflicting result could be explained by genetic and/or environmental factors. However, it has been demonstrated that even in Japan, the prevalences of both HTLV-1 and HAU vary from the North to the Southwest ${ }^{1223}$.

The 36.4\% (39/107) prevalence of KCS in HTLV-1 patients observed in Salvador is similar to the values detected in Minas Gerais, Brazil and Martinica ${ }^{1830}$. However, in São Paulo, Yamamoto et $a^{35}$ observed a KCS prevalence of $2.8 \%$ in infected carriers. This contradictory result could be explained by the fact that these HTLV-1 infected individuals did not have TSP/HAM. Herein, a positive association between the $\mathrm{fCS}$ and TSP/HAM was verified, corroborating previous data ${ }^{30}$. In fact, Pinheiro et al ${ }^{30}$ demonstrated that KCS prevalence was three times higher in TSP/HAM patients. Moreover, the significant association between KCS and TSP/HAM was maintained even after the adjusting for age and sex. Taken together, these results strongly suggest that HTLV-1 infection is associated with KCS and that the presence of TSP/HAM could influence the frequency of KCS.

We are aware that certain limitations exist in the present work, such as the absence of a HTLV-1 negative control. However, previous data have shown that in relation to KCS, a significant difference exists between HTLV-1 infected and non-infected individuals ${ }^{31}$. Additionally, sampling bias due to nonrandom sample selection could lead to an overestimation of the prevalence determined in this work. Further studies are required to elucidate these geographic differences, as well as the pathogenic mechanisms of CCS.

Finally, based on the results obtained, it is strongly recommend that HTLV-I patients undergo periodic ophthalmologic examination for early diagnosis and prevention of ocular diseases.

\section{ACKNOWLEDGEMENTS}

This article is part of the Masters (MSc) thesis of Regina Helena Rathsam Pinheiro, EBMSP, Postgraduate Course in Medicine and Human Health. The study was partially supported by National Research Council (CNPq).

\section{REFERENCES}

1. Barbosa HS, Bittencourt AL, Barreto de Araújo I, Pereira Filho CS, Furlan R, Pedrosa C, Lessa G, Harrington W Jr, Galvão Castro B.Adult T-cell leukemia/ lymphoma in northeastern Brazil: a clinical, histopathologic, and molecular study Journal of Acquired Immune Deficiency Syndromes. 21:65-71, 1999 .

2. Bloch-Michel E, Nussenblatt RB. International Uveitis Study Group Recommendation for the evaluation of intraocular inflammatory disease. American Journal of Ophthalmology 3:305-308, 2001.
3. Buggage RR, Levy-Clarke GA, Smith JA. New corneal findings in human T-cell lymphotropic virus type 1 infection. American Journal of Ophthalmology 131: 309-313, 2001.

4. Dourado I, Alcantara LC, Barreto ML, Teixeira MG, Galvão-Castro B. HTLV-I in the general population of Salvador, Brazil: a city with African ethnic and sociodemographic characteristics. Journal of Acquired Immune Deficiency Syndromes 34:527-531, 2003.

5. Edlich RF, Arnette JA, Williams FM. Global epidemic of human T-cell lymphotropic virus type-I (HTLV-I) The Journal of Emergency Medicine 18: 109-119, 2000.

6. Eguchi K, Matsuoka N, Ida H, Nakashima M, Sakai M, Sakito S, Kawakami A, Terada K, Shimada H, Kawabe Y, FukudaT, Sawada T, Nagataki S. Primary Sjogren's syndrome with antibodies to HTLV-I: clinical and laboratory features. Annals of the Rheumatic Diseases 51: 769-576, 1992

7. Farris RL, Gilbard JP, Stuchell RN, Mandel ID. Diagnostic Tests in Keratoconjuntivitis Sicca. The CLAO Journal 9:23-28, 1983.

8. Ferraz-Chaoui AK, Atta AM, Galvão-Castro B, Santiago MB. Study ofautoantibodies in patients with keratoconjuntivitis sicca infected by the human T cell lymphotropic virus type 1. Rheumatology International $2009 \mathrm{Jul} 29$. [Epub ahead of print].

9. Galvão-Castro B, Loures L, Rodriques LG, Sereno A, Ferreira Júnior OC, Franco LG, Muller M, Sampaio DA, Santana A, Passos LM, Proietti F. Distribution of humanT-lymphotropic virus type I among blood donors: a nationwide Brazilian study. Transfusion 37:242-243, 1997.

10. Gessain A, Barin E, Vernant JC, Gout O, Maurs L, Calender A. Antibodies to human T-lymphotropic virus type I in patients with tropical spastic paraparesis. Lancet 2:407-410, 1985 .

11. Gomes I, Melo A, Proietti FA, Moreno-Carvalho 0, Loures LA, Dazza MC, Said G, Larouzé B, Galvão-Castro B.Human T lymphotropic virus type I (HTLV-I) infection in neurological patients in Salvador, Bahia, Brazil. Journal of the Neurological Sciences 165:84-89, 1999

12. Ikeda E, Ono A, Hikita N, Arima K, Mochizuki M, Yamaguchi K, Tajima K, Kivokawa H. Estimated prevalence rate of HTLV-I uveitis in Chikugo. Nippon Ganka Gakkai Zasshi 102:327-332, 1998

13. Kashima S, Alcantara LC, Takayanagui OM, Cunha MA, Castro BG, Pombo-deOliveira MS, Zago MA, Covas DT. Distribution of human T cell lymphotropic virus type 1 (HTLV-1) subtypes in Brazil: genetic characterization of LTR and tax region. AIDS Research and Human Retroviruses 22:953-959, 2006.

14. Kanski JJ. Clinical Ophthalmology. A Systematic Approach. $5^{\text {a }}$ edition. Philadelphia: Butterworth Heinemann 5:270-308, 2003.

15. La Grenade L, Hanchard B, Fletcher V, Cranston B, Blattner W. Infective dermatitis of Jamaican children: a marker for HTLV-I infection. Lancet 336: 1345-1347, 1990.

16. Levine PH, Blattner WA. The epidemiology of diseases associated with HTLV-I and HTLV-II. Infectious Disease Clinics of North America. 1:501-510, 1987.

17. Levy-Clarke G, Buggage R, Shen DF, Vaughn LO, Chan CC, Davis JL. Human T-cell lymphotropic virus type-I associated T-cell leukemia-lymphoma masquerading as necrotizing retinal vasculitis. Ophthalmology 109: 1717-1722, 2002.

18. Merle H, Cabre P, Olindo S, Merle S, Smadja D. Ocular lesions in 200 patients infected by the Human T-cell lymphotropic virus type 1 in Martinique (French West Indies). American Journal of Ophthalmology 134:190-195, 2002.

19. Merle H, Donnio A, Gonin C, Jean-Charles A, Panelatti G, Plumelle Y. Retinal vasculitis caused by adult T-cell leukemia/lymphoma. Japanese Journal of Ophthalmology 49:41-45, 2005

20. Merle H, Smadja D, Le Hoang P, Bera O, Cabre P, Landau M, Vernant JC. Ocular manifestations in patients with HTLV-I associated infection: a clinical study of 93 cases. Japanese Journal of Ophthalmology 40:260-270, 1996.

21. Mochizuki M. Human T-lymphotropic virus type 1 and its ocular manifestations International Ophthalmology Clinics 107-120, 1995.

22. Mochizuki M, Ono A, Ikeda E, Hikita N, Watanabe T, Yamaguchi K, Sagawa K, Ito K. HTLV-I uveitis.Journal of Acquired Immune Deficiency Syndromes and Human Retrovirology 13 (Suppl 1):S50-56, 1996.

23. Mochizuki M, Watanabe T, Yamaguchi K, Takatsuki K, Shirao M, Yoshimura K,Nakashima S, Mori S, Araki S, Miyata N. HTLV-1 uveitis: a distinct clinical entity caused by HTLV-1. Japanese Journal of Cancer Research 83:236-239, 1992.

24. Mueller N. The epidemiology of HTLV-I infection. Cancer Causes Control 2:37-52, 1991 
25. Nakao K, Ohba N, Matsumoto M. Noninfectious anterior uveitis in patients infected with human T Lymphotropic virus type I. Japanese Journal of Ophthalmology 33:472-478, 1989.

26. Nunes C, Mascarenhas-Batista AV, Maltês D, Brandão JCD, Ferreira TS, Seabra AML. Características Clínicas-Epidemiológicas de 385 pacientes portadores de HTLV na Bahia. In: IX Simpósio Internacional sobre HTLV no Brasil; 2006 Set 19-22, Belo Horizonte, Brasil; Revista da Sociedade Brasileira de Medicina Tropical. $39: 71,2006$.

27. Oliveira M de F, Brites C, Ferraz N, Magalhães P, Almeida F, Bittencourt AL. Infective dermatitis associated with the human T cell lymphotropic virus type I in Salvador, Bahia, Brazil. Clinical Infectious Diseases 40:90-96, 2005.

28. Osame M. Review of WHO Kagoshima meeting and diagnostic guidelines for HAM/TSP. In: Blattner W (ed)Human Retrovirology: HTLV $1^{\text {st }}$ edition. Raven Press: New York p. 191-197, 1990

29. Osame M, Matsumoto M, Usuku K, Izumo S, Ijichi N, Amitani H, Tara M, Igata A. HTLV-1 associated myelopathy, a new clinical entity. Lancet 1:1031- 1032, 1986.

30. Pinheiro SR, Martins-Filho OA, Ribas JG, Catalan-Soares BC, Proietti FA, NamenLopes S, Brito-Melo GE, Carneiro-Proietti AB, InterdisciplinaryHTLV-I/II Research Group (GIPH). Immunologic markers, uveitis, and keratoconjuntivitis sicca associated with Human T-Cell lymphotropic virus type 1. American Journal of Ophthalmology 20: 1-5, 2006.
31. Poiesz BJ, Ruscetti FW, Gazdar AF, Bunn PA, Minna JD, Gallo RC. Detection and isolation of type-C retrovirus particles from fresh and cultured lymphocytes of a patient with cutaneous T-cell lymphoma. Proceedings of the National Academy of Sciences of the United States of America 77:7415-7419, 1980

32. Proietti FA, Carneiro-Proietti ACF, Catalan-Soares BC, Murphy EL. Global epidemiology of HTLV-1 infection and associated diseases. Oncogene 24:6058$6068,2005$.

33. Secretaria de Vigilância em Saúde. Guia do manejo clínico do HTLV (Série A Normas e Manuais Técnicos n. ${ }^{0}$ 3) Programa Nacional de DST e Aids. - Brasília: Ministério da Saúde, 2003.

34. Soares R, Moraes Jr H. Manifestações oculares observadas em indivíduos infectados por HTLV-I no Rio de Janeiro. Arquivos Brasileiros de Oftalmologia. 63:293-298, 2000.

35. Yamamoto JH, Segurado AA, Hirata CE, Sampaio MW, Souza EC, Nukui Y, Cliquet M, Saéz-Alquézar A, Olivalves E, Mochizuki M. Human T-lymphotropic virus type 1 infection and ocular manifestations in São Paulo, Brazil. Archives of Ophthalmology 117: 513-517, 1999.

36. Yoshida M, Miyoshi I, Hinuma Y. Isolation and characterization of retrovirus from cells lines of human adult T-cell leukemia and its implications in the disease. Proceedings of the National Academy of Sciences of the United States of America 79:2031-2035, 1982. 